
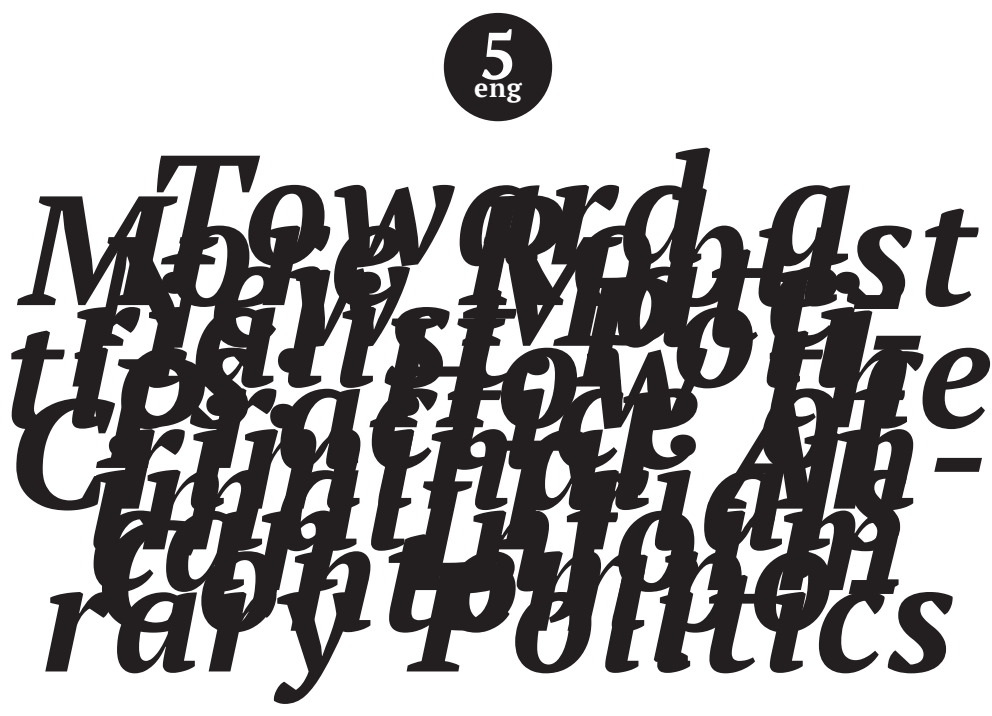

Zachary Low Reyna

Professor, School of Advanced Studies

University of Tyumen,

8 Marta St. 2k1, Tyumen, Tyumenskaya Oblast, Russian Federation E-mail:zel.reyna@gmail.com

\title{
Toward a More Robust New Materialist Politics: How the Practice of Criminal Animal Trials Can Inform Contemporary Politics
}

Abstract:

Prior to the twentieth century, animals were routinely put on trial in human courtrooms. This curious practice has received little academic attention. In this article, I examine the phenomenon of 
animal trials as an "old" New Materialism. Both part and parcel of the Western legal systems that gave rise to modern law and somehow excessive or extravagant to modern law, the practice of putting animals on trial provides insight into how occidental law and politics has traditionally grappled with the question of the nonhuman, and also the potentialities and shortcomings of

recent attempts to include the nonhuman in modern law and politics. The goal of this article is not to resuscitate these archaic practices, but to explore a path not taken by modern law, and so open a route for both deepening our appreciation of the historical possibilities of a New Materialist politics and pushing it further.

\section{Keywords:}

New materialisms, animal trials, Michel Serres, natural law, environmental politics

Prior to the twentieth century, animals were routinely put on trial in human courtrooms (Berman 2000; Cohen 1986; Evans 2009; Girgen 2003; McWilliams 2013). This curious practice has received little academic attention. ${ }^{1}$ In this article, I examine the phenomenon of animal trials as an "old" New Materialism. Both part and parcel of the Western legal systems that gave rise to modern law and somehow excessive or extravagant to modern law, the practice of putting nonhuman animals on trial provides insight into how occidental law and politics has traditionally grappled with the question of the nonhuman, and also the potentialities and shortcomings of recent attempts to include the nonhuman in modern law and politics. The goal of this article is not to resuscitate these archaic practices, but to explore a path not taken by modern law, and so open a route for both deepening our appreciation of the historical possibilities of a New Materialist politics and pushing it further.

The first section sets the stage by reviewing contemporary attempts to include animals in human law and politics. Here, I focus primarily on the diverse movement in the theoretical humanities and social sciences that has become known as the New Materialisms over the past decade. ${ }^{2}$ I identify three characteristics that I believe unites this otherwise piebald movement: 1 ) their critique of Kant's critical philosophy; 2) their argument that agency and knowledge are not something possessed by a subject but performed in tandem

\footnotetext{
${ }^{1}$ There are notable exceptions, which I discuss below (see also Berman 2000; Cohen 1986; Girgen 2003; Timofeeva 2018).

${ }^{2}$ I review this literature in Section One. For an introduction (see Coole and Frost (2010).
} 
with a myriad of other acting and knowing things; and 3) their emphasis on an ethics of humility that seeks to challenge what they see are the extravagances of modern, Western anthropocentrism. While promising as a critical academic movement, I worry that the New Materialisms have remained too theoretical and disconnected from the actual creaturely processes of living, dying, and doing politics. The result is that the New Materialisms now appear more than ever like an academic fad, a hot topic, that nonetheless offers very little toward a concrete political program or solution. ${ }^{3}$ This article seeks to begin to remedy this problem.

To do so, I turn to the premodern phenomenon of animal criminal trials. Such a move allows me to do two things. First, it allows me to bring some historical depth to New Materialist literature, showing how one does not need to look far abroad or to dense theoretical literature to find indigenous occidental resources for thinking about the vitality and liveliness of nonhuman matter. Second, it allows me to focus my critique of the New Materialisms in a more productive route. Rather than lambast the New Materialisms for their lack of political direction, I use the phenomenon of occidental animal trials to help me articulate a more politically oriented and practically focused New Materialist project.

\section{Coming to Terms with the New Materialisms}

Since the 1970s there has been a resurgence of interest in including nonhuman animals and objects in human law. If contemporary law by and large positions animals as outside or "before" the law - as objects to perhaps be protected by law, but not as legal subjects - then my wager in this article is that this is not occidental law's historical baseline or norm, but rather a modern anomaly that is beginning to look more and more like a short hiatus (see Wolfe 2012). The modern quest to include nonhuman animals and objects in our modern politics and law has at least two origins. The first stems from environmental legal attempts to claim rights - and not simply protection - for certain nonhuman aspects of nature. This trajectory has been primarily policy-oriented and reformist in character, working within modern legal systems. US Supreme Court Justice Douglas's dissent in Sierra Club v Morton (405 U. S. 727. 1972) marks an important and early chapter in this story as does Christopher Stone's Should Trees Have Standing (1972). Although ultimately unsuccessful in obtaining rights for nonhumans,

${ }^{3}$ I am not the first to make this criticism of the New Materialisms. See Cole (2013); Ferguson (2014). 
these pivotal early moments marked a shift in the humancentric hegemony of modern law. More recently, and outside the US, this movement has seen more practical success. Costa Rica and Ecuador for example have both included animal rights in their constitution and New Zealand has recently granted legal personhood to a river (Cullinan 2011; Roy 2017). While these developments are interesting and emphasize for me the instability of excluding animals from legal subjectivity, they do not form the center of what I want to focus on in this article. Although admirable and effective in a reformist sense-extending liberal rights to nonhumans in much the same way as nineteenth- and twentieth-century movements extended liberal rights to women and people of color - I worry that such a move does not go far enough in the direction of fundamentally rethinking how we do law and politics once the nonhuman is reincorporated.

In contrast, the New Materialist scholarship I focus on in this article has taken as its starting point a radical rethinking of what it means to do politics and cohabit a world in which humans are not the only meaningful actors. Central to this scholarship has been a sustained critique of the philosophical dualist distinction between mind/human/culture on the one hand and body/animal/nature on the other. Yet this philosophical focus has also meant that the New Materialisms have remained primarily academic and critical. In an almost ironic way, the New Materialisms have remained largely removed from the lives of the vast majority of earthlings that inhabit our planet even while theoretically pushing us to recognize the pedestrian, the everyday, the animals and objects that surround us. In this section I outline some of the key New Materialist tenets, before turning in the next section to the phenomenon of animal trials to bolster the potentialities of a New Materialist politics.

Coalescing at the end of the first decade of the twenty-first century in North America under the general banner of the New Materialisms, this movement has witnessed most of its success in academic and artistic circles. Part reaction to the linguistic turn's deprioritization of materiality, part realization of the dangers late capitalist society poses to the material world, and part despair with human-all-too-human subjects' capacity for revolution, the materialist turn challenges the mind-body, culture-nature binary in order to help us appreciate the ways nonhuman things - both organic and inorganic - act alongside humans rather than serving only as the background of human action. Consequently, a main target of the New Materialisms has been the philosophical distinction between a subjective, spiritual, and intelligent world inhabited by human 
beings and an objective, material, and mechanistic world inhabited by bodies, things, and physical forces.

Foreshadowed by the writing of continental thinkers such as Gilles Deleuze, Felix Guattari, Donna Haraway, Andrew Pickering, Isabelle Stengers, and Bruno Latour, the New Materialisms as a field of study came to prominence at the close of the first decade of this century with the publication of Diana Coole and Samantha Frost's edited volume New Materialisms: Ontology, Agency, and Politics (2010); Jane Bennett's Vibrant Matter: A Political Ecology of Things (2010); Karen Barad's Meeting the Universe Halfway: Quantum Physics and the Entanglement of Matter and Meaning (2007); Stacey Alaimo and Susan Hekman's Material Feminisms (2008); and Levi Bryant, Graham Harman, and Nick Srnicek's The Speculative Turn: Continental Materialism and Realism (2011). In the decade that has followed, there has been a veritable boomlet of scholarship developing these theories along vast and disparate trajectories: Object-Oriented Ontology, Feminist Materialism, Eco-materialism, Speculative Realism, Agential Realism, and so on. I look at three characteristics that I believe are shared across "New Materialist" literature broadly construed. ${ }^{4}$

\section{A. Ontology of the "Great Outdoors"}

The first strand uniting the New Materialisms is their insistence to return ontology, or the study of being, to a philosophical primacy it has not attained since Kant's critical turn in the eighteenth century. Jane Bennett has described this as an attempt to focus on the "traces of independence or aliveness, constituting the outside of our own experience" (Bennett 2010: xvi, own emphasis added).

\footnotetext{
${ }^{4}$ It is important to note that not all the scholars I consider in this section self-identify as "New Materialists." Indeed, among those I consider here, there is rife dissension that goes to the very heart of how to theorize matter, things, and objects. Does agency "withdraw" into the interior of an object as scholars such as Graham Harman and Timothy Morton have argued, or does agency emerge only in the pooled "intractivity" of assemblages as scholars such as Karen Barad, Jane Bennett, and Bruno Latour have argued? Is the goal to see currents of subjectivity or proto-subjectivity coursing through all elements of the universe or to de-subjectify the human subject, curiously observing the ways our bodies-even our wills and minds - behave more with the recalcitrance of objects than traditional intentional subjects? Should language be seen as an always and only material practice of tongues, breathe, and written words or is language's materiality somehow irreducible to the only physical? Because these are all open and hotly debated topics in what I take to be New Materialist scholarship, I use the term New Materialisms not to refer to a specific school of thought or particular take on these questions, but rather a tendency that has developed across the theoretical social sciences, humanities, and art world in the past fifteen or so years.
} 
Similarly, Quentin Meillassoux, albeit in a more aphoristic way, describes it as the attempt to access "the great outdoors, the absolute outside of pre-critical thinkers" (2010: 7). But to access this "great outdoors" requires circumnavigating what A. N. Whitehead (2015 [1920]) called the "great Bifurcation" or the dividing of reality into two fundamentally split categories: the thinking and experiencing subject endowed with agency and intentionality and a mute objective reality that we can only say exists for the subject, or as perceived by the subject.

The problem with this split, according to New Materialist literature, is not simply the ways it activates critical philosophy, but that that it is also hard to maintain in practice. Bruno Latour has been one of the most consistent advocates of this claim, demonstrating the many ways that in practice Western peoples do not maintain a clear-cut distinction between human subjects and material objects, despite professing such a belief at the philosophical level (Latour 1993 [1991]). Yet it is one thing to expose a dichotomy as problematic or even false and it is quite another thing to actively theorize alternatives. And here the New Materialists diverge along two clear trajectories in an illuminating way.

The modus operandi of the first approach has been to shift the focus away from what a thing is, to what it does, or what Jane Bennett calls "thing-power" (Bennett 2010: 2-20). That is to say, one New Materialist approach is to focus on the way things both human and more-than-human "make differences, produce effects, alter the course of events" (Ibid viii). A Spinozian and Deleuzian philosophy of immanence or horizontal ontology seems to pervade this approach. I take an example from Jane Bennett's Vibrant Matter to flesh out how this approach attempts to access the "great outdoors."

In Vibrant Matter, Bennett gives the example of a massive electrical blackout that occurred in North America during the summer of 2003 (Ibid: 20-39). Over a period of several days in August 2003, fifty million people over approximately fifteen thousand square miles were left without electricity. Over one hundred power plants were shut down including a score of nuclear reactors. Basements flooded, stores were looted, people were left in the dark and sweltering summer heat. At first blush, an electrical blackout seems like a distinctly human failure. Only humans make usable electricity, only humans build and maintain the lines to deliver electricity, and only humans use electricity (even if some of our nonhuman companions also reap the benefits and disadvantages of electricity). Yet, according to Bennett, the urge to identify a human agent to blame for the electrical failure-most fingers were pointed at the FirstEnergy company 
whose Lake Eerie power plant's failure may have precipitated the blackout-obscures rather than clarifies what happened. Instead, Bennett uses the 2003 blackout to focus attention on the way human concepts like responsibility and intentionality only make sense when seen as part and parcel of a complex network including human subjects, but also extending beyond them.

The electrical grid, Bennett writes is "a volatile mix of coal, sweat, electromagnetic fields, computer programs, electron streams, profit motives, heat, lifestyles, nuclear fuel, plastic, fantasies of mastery, static, legislation, water, economic theory, wire, and wood - to name just some of the actants" (Bennett 2010: 25). "Actants" is a term of art Bennett borrows from Latour's Actor Network Theory to mean something like an actor, but not with a strong sense of consciously possessed agency. The actant, unlike the actor does not possess his/her/its agency rather it is a node in the enactment of agency for Latour and Bennett. Bennett continues, "There is always some friction among the parts, but for several days in August 2003 in the United States and Canada the dissonance was so great that cooperation become impossible" (Ibid). In drawing our attention to the way human intentionality is only one actant among others, Bennett dislodges agency from its traditional resting place in the human subject or human collectivity to a human-nonhuman interactant web. True, human companies like FirstEnergy and human decision-making processes were certainly complicit in the blackout, as was the Federal Energy Regulatory Commission and other human governmental agencies, but also active in the blackout was the way electricity behaves sometimes unpredictably, tree-wire encounters and brush fires that downed lines and stressed other lines, computer programs that automatically threw plants offline when overstressed. "Electricity sometimes goes where we send it," Bennett concludes, "and sometimes it chooses its path on the spot, in response to the other bodies it encounters and the surprising opportunities for actions and interactions that they afford" (Ibid: 28). Bennett thus points to a world where the human being and human society in toto is just one actor among many others. A vibrant materialist world, in which human actions can only be understood through their relations to the nonhuman.

Coming from a different angle and drawing on Martin Heidegger instead of Spinoza, Deleuze, and Latour, but pointing to a similar account of things and objects as containing traces of independence that prevent them from being subsumed as the inert background of human activity, Graham Harman represents for me the second approach. Using Heidegger's famous discussion of tools in Being and 
Time, Harman argues that all things contain an element of withdrawal or self-withholding from - a reservoir of potential, whereby they can never be fully ordered, manipulated, or regulated by human beings (Harman 2005; 2009). In short, objects for Harman have a life of their own, independent of our particular projects. Unlike Bennett's approach, this second approach - often found more in the Object-Oriented Ontology or Speculative Realism sectors - does not focus on relationality and interconnectedness, but on how all objects including the most mundane withdraw from their relationality. Instead of privileging relationality and Deleuze's univocity of being, this second approach explicitly denies the fundamentality of relationality for which thinkers like Bennett argue.

For Harman, we access the "great outdoors" not in a thing's relationality, but in moments of relational breakdown, that is, when a thing ceases to be an effective member of a network. Drawing on Heidegger, Harman argues that it is when a hammer shifts from being the seamless ready-at-hand tool of the carpenter to the broken present-at-hand object, that we can catch a glimpse of the elusive and radical otherness of things. It is only in the moment of breakdown that we recognize a hammer is never only a tool for a human project, that is, a "correlate" of human existence, but exists as well in a netherworld of its own possibilities (Harman 2009).

Yet despite their differences, both approaches attempt to find ways to access what Kant's critical philosophy said was off limits to us: Bennett through stressing our similarity (univocity) as just one more actor in a web of interactants and Harman through providing us an over-the-shoulder glance at the object as it retreats into its independence (equivocity). ${ }^{5}$ It is this shared endeavor to access the ontology of the "great outdoors," namely, to articulate a mode of existing that can "listen to the call of things" that I believe unites the various thinkers of the New Materialisms. It is also an aspect that leads to New Materialisms' emphasis on receptivity, listening, and questions of ethics rather than action and politics. I turn now to flesh out this latter claim.

\section{B. Embodied Epistemology}

Just as a return to ontology can be understood as a uniting aspect of the New Materialisms, so too is their approach to epistemology. The second tenet that I believe unites the New Materialisms can

\footnotetext{
${ }^{5}$ For a more detailed reading of the New Materialisms as breaking down into a univocal and an equivocal camp, see Reyna (2018). Here I make the case for a Thomistic alternative to these two camps for the contemporary study of materiality.
} 
be framed as the claim that knowledge is enacted rather than possessed by subjects. Knowledge, in this view, is not the possession of subjects, but something in the world that subjects from time to time enact or "partake" in. In this vein, David Abrams asks, "What if mind is not ours, but is Earth's? ...What if like the hunkered owl, and the spruce bending above it, and beetle staggering from needle to needle on that branch, we all partake of the wide intelligence of this world" (1997: 262). For Abrams, the modern representationalist epistemology that posits a subjective knower over and against an objective reality misses that we first encounter enfleshed bodies trying to navigate a world and only upon secondary reflection get to the philosophical subject.

Physicists Andrew Pickering and Karen Barad are more systematic in their critique of the traditional representationalist epistemology. Pickering argues for what he calls a "mangle of practice," evoking the old-fashioned laundry mangle that dried clothes by smooshing and wringing them between two rollers. Practice - a bodily activity - and knowledge emerge for Pickering (1995) as literally wrung out together. The human scientist does not stand apart from the world as an external observer, but acts within the world and as an integral piece of the world. Barad goes even further, arguing that all knowledge is always only "part of the universe making itself intelligible to another part" or what she calls the "intractivity" of the universe instead of its "interactivity" (2007: 143). Focusing on matters of practices, doings, and actions, Barad argues for the philosophical priority of "phenomena" (Ibid: 121). "Phenomena," Barad writes, "are ontologically primitive relations - relations without preexisting relata" (Ibid: 133). In making this move, Barad, like Pickering and Bennett, rejects a Kantian tradition that subordinates phenomena to a more real realm of noumena. "Relata," or the discrete things that together compose a relation, "do not preexist relations; rather, relata-within-phenomena emerge through specific intra-actions" (Ibid: 134). "Agency is not," Barad concludes, "an attribute," or something that might belong to something, "but the ongoing reconfigurings of the world" (Ibid: 135).

For these New Materialists, action happens, knowledge is produced, both are something done alongside others-enactments rather than something possessed or done by a sovereign subject. Just as the New Materialisms' emphasis on ontology beckons us to "listen to the call of things" rather than construct the world in our own image - a traditional and often emancipative goal of modern politics - the emphasis on the embodiment and enactment of knowledge challenges our belief in something we might call the discrete, 
definable human subject, which in liberal modernity has been the locus of political action. Consequently, the New Materialism's embodied epistemology also contributes to the difficulty of imaging what a New Materialist politics would look like.

\section{An Earthly Ethics of Humility}

The third and final characteristic that I believe unites the New Materialisms is closely related to the first two. If the New Materialisms are united in their arguments that we can be receptive to a reality outside human experience and that our knowledge and agency is always a co-enactment including the nonhuman, they seem equally united in their normative conclusion: an ethical call to pay more attention to this outside. In short, to be more humble, to chasten our anthropocentrism. In her response to Graham Harman, Bennett (2012) articulates the centrality of humility to the New Materialist project, stressing that it is the "shared" project between Harman and herself.

Practitioners and critics alike have described this as the New Materialisms' "ethical" moment (Bennett 2012; Cole 2013; Kang 2019). Namely, the moment in which we find the normative payoff of the worldview shifts in ontology and epistemology - characteristics one and two above respectively - that the New Materialists call us to. Central to the New Materialist project then is not only a new or more embracive way of seeing the world and our human part in it, what the critic Andrew Cole (2013) points out as in fact nothing new, popular science magazines have been pointing this out for decades, but also an ethical change of heart, we might say.

Here we find what appears to me as the "project" of these New Materialisms: a chastened appreciation for human knowledge and agency and more openness to the outside, to listening to the call of things. This project, as New Materialists like Bennett argue, is primarily an ethical project - or what Deleuze might call "micropolitcs" - a shift in worldview that includes, at least for Bennett, an array of Foucauldian "techniques of self" for learning to be more receptive to this outside (Bennett 2010: 14-15, 43, 114). It is illuminating, I believe, to look closely at how one thinker actually expresses this normative payoff. In Reassembling the Social, Latour describes his method as one of giving objects voice, of "making them talk":

To be accounted for, objects have to enter into accounts. If no trace is produced, they offer no information to the observer and will have no visible effect on other agents. They remain silent and are 
no longer actors: they remain, literally, unaccountable. Although the situation is the same for groups and agencies - no trial, no account, no information - it is clearly more difficult for objects, since carrying their effects while becoming silent is what they are so good at as Samuel Butler noted. Once built, the wall of bricks does not utter a word-even though the group of workmen goes on talking and graffiti may proliferate on its surface [...]This is why specific tricks have to be invented to make them talk, that is, to offer descriptions of themselves, to produce scripts of what they are making others - humans and nonhumans - do. (Latour 2005: 79)

In contrast to some of the main criticisms of New Materialist scholarship - namely, that it assumes things have voices that only need to be listened to-Latour emphasizes the many techniques that are required to go into giving an object voice. More recently, Latour has gone as far as to describe this project as convoking "a parliament of things" (2004: 227). Showing us how humans also need representatives to have a voice in parliamentary systems of governance - they are not "born" with voice, but voice is produced in them through a series of techniques and representations - Latour argues that it should come as no surprise that nonhuman animals and objects also need to be provided representatives to give them a voice.

Two things are important about this example. First, I think it is helpful in resisting the critical claim that the New Materialisms simply assume they need to listen to the call of things without inquiring into how these calls and voices are produced (Cole 2013; Kang 2019). This claim tends to be an over-exaggeration, at least for the New Materialists considered here. Latour is adamant that things do not simply have voice, but voice is produced in them through a series of techniques and practices. Here the political and legal language of the New Materialisms is most evident with terms like "parliament" and "voice" and "representation." Second, despite the political and legal language that the New Materialisms rely on here, their project remains primarily ethical, individual, and micropolitical. In other words, despite drawing on the language of institutional politics, Latour remains far from advancing specific institutional changes as I show below. Consequently, even here where they explicitly deploy traditional political language, the New Materialisms remain overwhelmingly focused on the ethical, on the virtue of humility, and of becoming more individually sensitive to the voice of things.

While Latour in particular seems to push this in a critical direction, recognizing the way all voice - including human voice - must be constructed, he remains woefully silent on the actual institutional 
work that will need to be performed into order to hear these voices. Even in his much more recent Gifford Lectures, Latour (2017) has remained vague, alerting us to the necessity of thinking about how we will give voice to things like the Gulf Stream, but concluding with fascination rather than an answer. I believe this marks a serious shortcoming of New Materialist scholarship. Rather than see this ultimate turn to politico-legal terminology as a symptom of the inability to keep pushing the New Materialisms in a philosophical and/ or micropolitical register, they seem to double down on their ethical claim that we must listen to the call of things, assuming that we are either just talking too loudly to hear it or simply do not yet have the techniques to hear it.

This means that for the New Materialisms, the problem remains a subjective problem, one we need to fix with ourselves - individually and collectively - rather than a problem with the links and ties that connect us to a shared world, which I argue in the next section is a political problem. I believe this is one of the reasons why the New Materialisms have remained largely an academic and artistic movement, rather than a political movement. The problem is not only that the New Materialisms perform a radical critique of concepts central to traditional Western politics - action, subjectivity, and institutions - but they further seem to harbor a certain disdain for the institutional practice of law and politics, focusing instead on ethical transformation and micropolitical concerns. I do not doubt that these moves have been fueled by well-intending critical energies, but I do worry they leave the New Materialisms open to the charges of being distant, abstract, and bourgeois, as well as leaving them open to being co-opted by a wide variety of contrary political positions, unless they more soundly connect themselves up with a clearer and concrete political program. ${ }^{6}$ I turn now to the phenomenon of animal trials in the pre-twentieth century occident to see if we might find resources for sketching the contours of what this political program might be.

\section{Animal Criminal Trials}

In the late sixteenth century, the weevils of Saint Julien in southern France were taken to court. ${ }^{7}$ Weevils are a type of beetle. They are usually small, measuring less than six millimeters, and are gen-

\footnotetext{
${ }^{6}$ Jodi Dean (2009) has begun to sketch the dangerous terrain onto which a New Materialism without a more secure political anchor might be pulled in.

${ }^{7}$ See Evans (2009: 38-49) for a full account. Evans documents nearly two hundred examples of nonhuman animals and "inanimate things" being tried in courts of law throughout Europe and the colonial Americas.
} 
erally considered a "pest species" because of their ability to reproduce quickly and wreak havoc on human crops when conditions are in their favor. And the weevils of Saint Julien had done just that, decimating the district's highly prized grape crop. The sobered human vintners decided to take legal action. Taking legal action against nonhuman animals and objects was not unusual practice in the West prior to the twentieth century despite its quaint, outlandish flavor today (Evans 2009; Kirton-Darling 2018; Pietz 1997). Indeed, the weevils of Saint Julien had faced legal prosecution before. About thirty years earlier in the spring of 1546, similar crop-destructive activity landed the weevils (or at least their forbearers) in court. At that time, the weevils' two appointed human lawyers were able to avoid trial. This time however, the weevils' newly appointed lawyer, Pierre Rembaud, would not be so effective.

Rembaud first argued that the case should be dismissed, claiming that the weevils had a prior right to the vineyards insofar as God created weevils before human beings according to the biblical narrative of creation. But the judge rejected Rembaud's motion for dismissal. While weevils may have been created prior to human beings, the judge reasoned, it is not clear that vineyards existed in this interim post-"creeping things" and pre-"man" period. The trial thus proceeded with both sides presenting lengthy and sophisticated arguments that Evans presents with some detail (2009: 38-49).

All the while though, the weevils kept up their ravaging of the vineyards. Anxious for a speedy resolution, the human vintners organized a public meeting to debate the allocation of a specific plot of land on the outskirts of town for the express use of the weevils. This meeting concluded with the selection of a plot named "La Grand Feisse" and which the plaintiff's attorney subsequently described "with the exactness of a topographical survey" to the court (Ibid: 46-47). Rembaud was not happy though. On behalf of his insect clients, he countered, insisting that the proposed plot was "barren" and therefore an unsuitable alternative to the lush present confines of his clients. Acknowledging Rembaud's motion, the judge decided to appoint a group of experts to assess the viability of "La Grand Feisse" for weevil habitation and ordered that a written report be submitted to the court. Ironically, this is all we know about this case. The next page of the records has been destroyed by "either rodents or insects" (Girgen 2003: 104). How are we to understand this queer, but once common practice? And more importantly for my argument here, how can understanding these animal trials help us articulate a more politically oriented New Materialist project? 


\section{Making Sense of Animal Trials}

Few scholars today address the prevalence of criminal animal trials in the pre-twentieth century occident. When they do, the most typical response is to interpret the phenomenon as "childish" play or as a superstitious remnant of an earlier "animistic time" that positions the animal or object as some curious subject of proto-liberal rights. ${ }^{8}$ Others such as Peter Leeson and Esther Cohen have acknowledged the procedural and institutional seriousness that attended these trials as a counterweight to the "childish" interpretation, but still primarily view these trials in a negative light. Peter Leeson (2013) suggests that animal trials were nothing but a thinly veiled attempt by ecclesiastical and secular courts to assert more authority over the governance of everyday social life. What better way to do this than expanding the court's jurisdiction? What was first just a vermin infestation now becomes a legal matter, requiring those humans facing the infestation not only to work to remove the weevils, but also appear in court. In a similar vein, Esther Cohen reads the phenomenon of animal trials as an attempt to extend the net of human legal authority. "If man was to rule nature," Cohen writes, "he must do so according to the same principles that governed his relationships with his fellow human beings" (1986: 36). ${ }^{9}$ For Cohen, Western animal trials can thus be seen as an integral part of Western man's progressive quest to dominate the world both human and nonhuman.

According to this second group of interpreters, the seriousness and procedural detail put into animal trials requires us to view them as something more than childish superstition à la Hans Kelsen or Evans. I believe Cohen and Leeson are correct in showing us there is more to the phenomenon of animal trials than superstition, but I disagree on what this more actually is. For Cohen and Leeson, the animal trials should not be viewed as irrational superstitious activity, but the rational attempt by certain human actors to extend their power and authority through institutional means. While helping us see the rational and institutional elements of these trials - instead of hubristically writing them off as nonsense - these interpretations go a long way in making sense of the very real social function these trials performed. However, it seems too hasty to me assume that

8 "Childish" is exactly how Evans (2009), the foremost collector of these cases, describes them. He is joined in such statements by other prominent twentieth-century legal thinkers like Hans Kelsen (2014). For similar but more recent interpretations, see Sykes (2011); Ridler (2013).

${ }^{9}$ Another notable proponent of this view is Berman (2000). 
this function is reducible to an attempt to extend human legal and cognitive control. In practice, animal trials were horribly ineffective in their attempts to govern the nonhuman world. Animal defendants almost never showed up for their court dates, rarely complied with court orders, were notorious repeat offenders (remember the weevils), and by and large remained just as ungovernable as ever despite all the seriousness put into the animal trials. It is thus worth reflecting a bit more on what else the seriousness put into animal trials might disclose about law, politics, and the nonhuman, as well as the prospects it opens for the articulation of a New Materialist political project.

Evans recounts that it was common legal practice when animal defendants were "evicted" from certain fields or habitats that they be granted legal "safe passage away from the vicinity, free of possible harm from dogs, cats, or other enemies" (2009: 48). ${ }^{10}$ This was the case of a mole trial in Stelvio, Italy in 1519. In this case, in a court decision that was not unusual, the judge even went further to grant any pregnant mole, mole with young children, or moles for whom the move would be stressful "an additional respite of fourteen days" to undertake the relocation (Ibid: 113). It was also often the case that a "suitable" alternative habitat needed to be provided when animal defendants were evicted and this was not a mere gesture, but a serious legal inquiry. This is observable in the weevil case I discussed above. In this case, a specific named plot "La Grand Feisse” was designated for the weevils' express use and even described "with the exactness of a topographical survey" by the plaintiff's attorney. Yet this was not enough to persuade the court that the plot was a suitable alternative. The judge appointed a group of experts to assess the viability of the plot for the weevils' use and submit a written report. In similar fashion, great care was taken in the legal proceedings determining the relocation of a brood of termites standing trial for eating away at a Franciscan monastery in Brazil in 1713 (Ibid: 123).

On the other end of the spectrum, executions of convicted animals, when they happened - and they did happen although we can safely estimate less routinely than in today's regime of pest control and extermination - were meted out with a high level of sobriety, eyewitness testimony, crosschecking, and corroboration of evidence that bespeaks great seriousness rather than "childishness" or "irrational barbarism." So, for example, when a sow and her six piglets stood trial in 1457 in Savigny, France for trampling and killing a small human child, no less than eight human eyewitnesses were called in order to establish "beyond reasonable doubt that the sow had killed the child"

${ }^{10}$ See also Teubner (2006). 
(McWilliams 2013). The piglets, however, were exonerated. Although they were found at the crime scene splattered with the human victim's blood, the eyewitnesses established that unlike the mother sow, the piglets were "never seen directly attacking the child" (Evans 2009: 140; McWilliams 2013). Similarly, in a bestiality case from 1750 in which a male human and female donkey were both charged, careful written testimony of the townspeople submitting that "in word and deed and in all her habits of life [this particular donkey was] a most honest creature" procured her exoneration (Evans 2009: 150). The man, however, was hanged from the gallows. There is no record to indicate whether the demure donkey ever pursued any future interspecies romances or any future romances at all for that matter.

How are we to understand the seriousness, high level of legal rationality, and complex institutional maneuvering with which these animal trials were approached? Even those scholars like Cohen who do accept the animal trials as a complex legal phenomenon worthy of scholarly research, do so in a very limited way, focusing on the trials as an attempt to extend human order and power over the nonhuman world. The problem with this, I have argued, is not merely that such interpretations fail to recognize the inefficacy of these trials in securing that goal of increasing human power, but that they also import a very modern conception of law. In attempting to uncover the "social function" or "utility" of animal trials, these scholars assume a very utilitarian notion of law and social function that many other scholars have shown did not exist until the nineteenth and twentieth centuries. Indeed, HLA. Hart (2012), one of the main proponents of this utilitarian view of law, argues that the view did not even exist before the early legal positivist work of Jeremy Bentham and John Austin. Hart shows that the linking of law with its social utility was the great invention the early legal positivists used to combat traditional natural law theory and its metaphysical assumptions. While this does not necessarily mean that these social utility interpretations of animal trials, such as Cohen's, are flat wrong, it does obscure possible non-utilitarian reasons that I believe are important to consider when we think about the possibilities of a New Materialist law and politics. In reducing law to its utility, these legal positivist interpretations of the animal trials thus run the risk of closing out alternative interpretations that do not fit neatly with legal positivist and utilitarian assumptions.

If these legal positivist interpretations are correct, and animal trials were a "charade of power" meant to consolidate court authority, then the phenomenon of animal trials massively overshot their mark in their excesses and institutional extravagances. Burdening the 
vintners with a court appearance because of a weevil problem is one thing, but there is an excess to the trials and their proceedings that cannot be easily fit into this account. Why, for example, worry about the plight of the weevils in their new habitat especially if the human participants knew they would not comply with court orders, or why seek eight eyewitness accounts to convict the sow and exonerate her piglets? It is not at all clear that this institutional rigor served the utility of extending human power. And yet people across vast swaths of time, space, and language clung to such practices. Why?

\section{The Institutional "Celebration of our Pact with the World"}

In The Natural Contract (1995 [1990]), French philosopher Michel Serres begins to develop what I believe is an answer. In typical Serres fashion, the book is racked with achingly poetic prose, but contains a number of insights that I believe can help us make sense of animal trials and their prospects for aiding us in articulating a more politically oriented New Materialist project. Moving beyond and expanding the utilitarian interpretation of law advanced by Hart and the legal positivists that sees law as a social tool, Serres defines law as "the refined technology of our relations" (1995: 45). Yet unlike the legal positivists who root this function in social control or the expansion of human instrumental rationality, Serres pushes his account of law's origin back into the religious and mythological registers. According to Serres, laws are not merely tools for controlling society or even creating society, but feature as the very material or "stuff" of society and the relations that compose society. Serres writes, "laws steady society by using ponderous objects to weigh down fickle subjects and their unstable relationships [...] materialize our relations and changes them into things. If our relations fluctuate, this solidification settles them" (Ibid). While Serres does not deny that law distributes power and exercises control over society, this aspect is secondary to law's more primary function of giving thingness to our immaterial, subjective relationships. Law, for Serres, is the very stuff of our being-together, without which our being-together would have no substance.

Importantly for Serres (Ibid: 104), we would be amiss to see this being-together as limited to humans. In one of the most evocative sections of the book, Serres fleshes out this claim. In a dense passage that is worth reading in its entirety, Serres writes:

We are constantly losing our memory of the strange acts that priests used to practice alone in somber and secret nooks, where they would 
dress the statue of a god, adorn it, ready it, raise it up or take it out, prepare a meal for it and talk to it constantly. They would do this every day and every night, at dawn and at dusk, when the sun and the shade reached their apogee. Were they afraid that a single pause in this continuous, infinite upkeep and conversation would open the door to tremendous consequences? Amnesiacs that we are, we believe that they adored the god or goddess sculpted in stone or wood. No: they were giving to the thing itself, marble or bronze, the power of speech, by conferring on it the appearance of a human body endowed with a voice. So they must have been celebrating their pact with the world [...] They are not following time, but sustaining it. Their shoulders and their voices, from biblical verses to orisons, bear each minute into the next throughout duration, which is fragile and would break without them [...]And what if it turned out that human history and tradition exist simply because men devoted to the longest term conceivable have never stopped sewing time back together? (Serres 1995: 47)

Although poetic, I take Serres's point to be very concrete here: our relationships with the nonhuman require just as much care and work as our relationships with other humans. This should in no way subtract from the work and care we put into our relationship with other humans, but it should push us to see that the nonhuman is not some basal background that can be safely assumed, but something with which a relationship must be pursued and worked at. In this sense, Serres helps give the lie to the late-modern belief that premodernity was a time of effortless harmonious belonging and enchantment. Indeed, Serres points to the incredible amount of work that used to go into maintaining human communities' bond to the nonhuman.

Serres concludes the above-quoted section arguing that the most pressing problem confronting us today is the "neglect," literally to deny the bond or ligament, of this work of maintaining our bond with the nonhuman:

Modernity neglects speaking in absolute terms [...] through exclusively social contracts, we have abandoned the bond that connects us

${ }^{11}$ The observation that work must go into this "pact" is not unique to Serres. I believe it is possible to sketch a "minor tradition" in the Western philosophical canon that tries to make it explicit: from Sophocles and Aquinas's natural law meditations to Nietzsche's "remain faithful to the earth" (2006), Whitman's “corroborate the theory of the earth" (1985), Deleuze's "restoring belief in this world” (1986), and various ethical sensibilities and micropolitical agendas today. The difference I am trying to emphasize here is that the work of maintaining this pact, which was once institutional, has become subjectivized, a matter of "faith," "belief," and "ethos" rather than legal practice. 
to the world, the one that binds the time passing and flowing [French, "temps"] to the weather outside [French, "temps"], the bond that relates the social sciences to the sciences of the universe, history to geography, law to nature, politics to physics, the bond that allows our language to communicate with mute, passive, obscure things. (Serres 1995: 48)

Serres makes clear here that what we moderns neglect is not only the religious aspects of this bond with the nonhuman, but also the politico-legal institutional work that went into maintaining this pact or bond. Unfortunately, Serres does not give details on what this work looked like. Nevertheless, I do not think I would be far off the mark to suggest that the phenomenon of animal trials and all the institutional work that went into them was one crucial element of this work.

Ultimately then, what Serres can help us begin to see is that in attributing legal status to the nonhuman, the practitioners of animal trials may have been working out and caring for their relationship to the nonhuman and not simply acting childishly or attempting to extend their instrumental power. The early twentieth-century legal anthropologist Bronisław Malinowski made an important analogous observation regarding non-Western customary societies in his influential monograph Crime and Custom in Savage Society (2014 [1926]). Criticizing the Durkheimian assumption of "spontaneous solidarity," Malinowski (2014 [1926] details the complex institutional legal work that went into creating and maintaining this solidarity. Just as non-Western "customary law" required careful institutional work that seriously problematizes the antiquated belief that these societies simply hung together naturally, Serres helps us come to terms with our late-modern conceit-still quite prevalent-that premodernity was a time of effortless and harmonious belonging, a time of enchantment. This is a conceit that continues to be quite common in critical work today. ${ }^{12}$ Serres, however, shows us that the harmony and belonging between human and nonhuman that we typically attribute to the premodern was not at all given or natural, but hard-worked. Human communities worked to maintain the bonds which gave them and their institutions a place within an unruly and at times unpredictable nature. And it is the institutional neglect of these bonds and relations, Serres concludes, that has allowed for the modern silencing or objectification of nature (1995: 48).

12 See Foucault's (2012) discussion of the "prose of the world.” Bruno Latour (1993 [1991]) and Jane Bennett (2001) both problematize this rhetoric, but by showing that what we call modernity has its own "enchantment" rather than revealing the work that goes into enchantment as I have attempted to do in this article. 


\section{Conclusion}

My goal in this article has been to articulate a more robust New Materialist politics. In the first section I reviewed New Materialist scholarship, pulling out three shared characteristics. I argued that despite the New Materialisms' critical approach, each of these characteristics ultimately frames the New Materialisms as an ethical rather than political project. If the New Materialisms have been as inept at generating a concrete political program to the same extent as the "old" or dialectical materialisms were adept at it, I do not believe this is because individual New Materialist practitioners are not interested in politics, but because New Materialist literature, by and large, has positioned itself as rejection of traditional political concepts.

Focused as they are on getting us to perform a worldview shift, the New Materialisms' keywords are receptivity, listening, nonhuman, and humility, rather than action, collective struggle, political subjectivity, and institutional change. I do not believe this is an unbridgeable gap or that what we really need is a return to the old dialectical materialism of Marx and his heirs as some critics assert (Cole 2013). Rather, in this article I turned to the phenomenon of animal trials as an "old" New Materialism in order to 1) inquire how occidental law and politics has traditionally grappled with the question of the nonhuman; 2) emphasize the importance of macropolitical institutional work and not just ethical transformation; and 3) dispel the myth that conventional Western political concepts like the human, subjectivity, action, and the pursuit of a more just and humane world are incompatible with New Materialist insights.

In short, if nonhuman animals and objects do not talk today, perhaps it is not because we have simply forgotten how to listen to them or have become deafened by our modern anthropocentrism, but because, as Serres would have it, we have neglected one of the most central institutional political tasks: "celebrating [our] pact with the world" (Serres 1995: 47). In closing, I would like to put forward three action points a New Materialist politics might pick up.

1. Any New Materialist politics worth its salt should resist the temptation to slide into the micropolitical and ethical registers at the expense of political action and politico-legal institutional work. More sustained efforts need to be focused at the institutional level, in not just lobbying or seeking to reform contemporary liberal democracies, but in formulating, implementing, and maintaining new and revised politico-legal institutional practices for celebrating and renewing our bond with the nonhuman as animal trials once did. Only this will 
ultimately allow us to hear the call of things, because only this will produce within these nonhuman things the voice with which to speak.

2. A New Materialist politics should not jettison the conventional humanist concepts of Western political thought but vouch for and make good these old humanist dreams. This means what we need are not only more creative and receptive approaches to the nonhuman, but also the reactivation of the political goals of the old dialectical materialisms which Max Horkheimer summarized as the "turn[ing of] blind resignation into understanding and hope” (1947: 115). I am not alone in making this claim. Kathy Ferguson (2014) has promoted it, as have Timothy Morton (2013) and Oxana Timofeeva (2013). As I see it, the goal is to actually deliver on the conventional humanist dreams that have long inspired Western thinking, rather than ditch them or seek to move beyond them as something too quaint or tried and found wanting. ${ }^{13}$ To do so does not mean neglecting the nonhuman, but mobilizing the nonhuman in our shared fight for a more just world.

3. We need to pursue a red-green coalition that brings together the fight for class equality with the fight for an ecological society. This is an extension of the previous point. Joel Kovel (2007), Michael Lowy (2015), and Naomi Klein (2015) have been active here.

\section{References}

Abrams, David (1997). The Spell of the Sensuous. New York: Vintage.

Alaimo, Stacey, and Susan Hekman (2008). Material Feminisms. Bloomington: Indiana University Press.

Barad, Karen (2007). Meeting the Universe Halfway: Quantum Physics and the Entanglement of Matter and Meaning. Durham, NC: Duke University Press.

Bennett, Jane (2001). The Enchantment of Modern Life. Princeton, NJ: Princeton University Press.

Bennett, Jane (2010). Vibrant Matter: A Political Ecology of Things. Durham, NC: Duke University Press.

Bennett, Jane (2012). "Systems and Things: A Response to Graham Harman and Timothy Morton.” New Literary History 43.2: 225-33.

${ }^{13}$ Perhaps Marx summed it up best in his 1843 letter to Arnold Ruge: "Our programme must be: the reform of consciousness not through dogmas but by analyzing mystical consciousness obscure to itself, whether it appear in religious or political form. It will then become plain that the world has long since dreamed of something of which it needs only to become conscious for it to possess it in reality. It will then become plain that our task is not to draw a sharp mental line between past and future, but to complete the thought of the past. Lastly, it will become plain that mankind will not begin any new work, but will consciously bring about the completion of its old work" (Marx 1991 [1843]). 


\section{Zachary Low Reyna}

Berman, Paul Schiff (2000). “An Observation and a Strange but True 'Tale': What Might the Historical Trials of Animals Tell us about the Transformative Potential of Law in American Culture?" Hastings Law Journal 52.1: 123-78.

Bryant, Levi, Graham Harman, and Nick Srnicek, eds. (2011). The Speculative Turn: Continental Materialism and Realism. Melbourne: Re.press.

Cohen, Esther (1986). “Law, Folklore, and Animal Lore.” Past \& Present 110.1: 6-37.

Cole, Andrew (2013). “The Call of Things.” The Minnesota Review 80: 106-18.

Coole, Diana, and Samantha Frost (2010). New Materialisms: Ontology, Agency, and Politics. Durham, NC: Duke University Press.

Cullinan, Cormac (2011). Wild Law: A Manifesto for Earth Justice Second Edition. Hartford, VT: Chelsea Green Publishing.

Dean, Jodi (2009). Democracy and Other Neoliberal Fantasies: Communicative Capitalism and Left Politics. Durham, NC: Duke University Press.

Deleuze, Gilles (1986). Cinema 2. Trans. Hugh Tomlinson. Minneapolis: University of Minnesota Press.

Evans, Edward (2009). The Criminal Prosecution and Capital Punishment of Animals [1906]. Clark, NJ: Lawbook Exchange Ltd.

Ferguson, Kathy (2014). "Anarchist Printers and Presses: Material Circuits of Politics.” Political Theory 42.4: 391-14.

Foucault, Michel (2012). The Order of Things: An Archaeology of Human Sciences [1966]. New York: Vintage.

Girgen, Jen (2003). "The Historical and Contemporary Prosecution and Punishment of Animals.” Animal Law Review 9: 97-133.

Harman, Graham (2005). Guerilla Metaphysics: Phenomenology and the Carpentry of Things. Chicago: Open Court.

Harman, Graham (2009). Prince of Networks: Bruno Latour and Metaphysics. Melbourne: Re.press.

Hart, HLA (2012). The Concept of Law [1961]. Oxford: Oxford University Press.

Horkheimer, Max (1947). The Eclipse of Reason. Oxford: Oxford University Press.

Kang, Hyo Yoon (2019). "Legal Materiality." In The Oxford Handbook of Law and Humanities, ed. Simon Stern. Oxford: Oxford University Press. https://www.oxfordhandbooks.com/view/10.1093/oxfordhb/9780190695620.001.0001/oxfordhb-9780190695620-e-9

Kelsen, Hans (2014). Pure Theory of Law [1960]. Clark, NJ: Lawbook Exchange, Ltd.

Kirton-Darling, Edward (2018). "Searching for Pigeons in the Belfry." Law, Culture and Humanities 41.3: 439-61.

Klein, Naomi (2015). This Changes Everything: Capitalism vs. the Climate. New York: Simone and Schuster.

Kovel, Joel (2007). The Enemy of Nature: The End of Capitalism or the End of the World? London: Zed Books.

Latour, Bruno (1993). We Have Never Been Modern [1991]. Trans. Catherin Porter. Cambridge, MA: Harvard University Press.

Latour, Bruno (2004). The Politics of Nature. Trans. Catherin Porter. Cambridge, MA: Harvard University Press.

Latour, Bruno (2005). Reassembling the Social. Oxford: Oxford University Press.

Latour, Bruno (2017). Facing Gaia. Trans. Cather Porter. Cambridge: Polity.

Leeson, Peter (2013). “Vermin Trials.” The Journal of Law and Economics 56.3: 811-36.

Lowy, Michael (2015). Ecosocialism: A Radical Alternative to Capitalist Catastrophe. Chicago: Haymarket Books.

Malinowski, Bronisław (2014). Crime and Custom in Savage Society [1926]. Mansfield, CT: Martino Publishing.

Marx, Karl (1991). “Letter from Karl Marx to Arnold Ruge” [1844]. Marxist Internet Archive. https://www.marxists.org/archive/marx/works/1843/letters/43_09-alt.htm

McWilliams, James (2013). “Beastly Justice.” Slate, 21 Feb 2013. https://slate.com/ 
human-interest/2013/02/medieval-animal-trials-why-theyre-not-quite-as-crazyas-they-sound.html.

Meillassoux, Quentin (2010). After Finitude. London: Bloomsbury.

Morton, Timothy (2017). Humankind: Solidarity with Nonhuman People. London: Verso.

Nietzsche, Friedrich (2006). Thus Spoke Zarathustra. Trans. Adrian Del Caro. Cambridge: Cambridge University Press.

Pickering, Andrew (1995). The Mangle of Practice: Time, Agency, and Science. Chicago: University of Chicago Press.

Pietz, William (1997). "The Death of the Deodand.” RES: Anthropology and Aesthetics 31: 97-108.

Reyna, Zachary Low (2018). “Aquinas's Ecological Vision: Natural Law and Friendship in Contemporary Environmental Political Thought.” New Political Science 40.1: $15-32$.

Ridler, Victoria (2013). "Dressing the Sow and the Legal Subjectivation of the Non-human Animal." Law and the Question of the Animal: A Critical Jurisprudence, ed. Edward Mussawir, 102-15. New York: Routledge.

Roy, Eleanor Ainge (2017). "New Zealand Rive Granted Same Legal Rights as Human Being.” The Guardian, 16 March 2017. https://www.theguardian.com/world/2017/ mar/16/new-zealand-river-granted-same-legal-rights-as-human-being.

Serres, Michel (1995). The Natural Contract [1990]. Trans. Elizabeth MacArthur and William Paulson. Ann Arbor: University of Michigan Press.

Stone, Christopher (2010). Should Trees Have Standing? Law, Morality, and the Environment. Oxford: Oxford University Press.

Sykes, Katie (2011). “Human Drama, Animal Trials.” Animal Law Review 17.2: 273-312.

Timofeeva, Oxana (2018). The History of Animals: A Philosophy. London: Bloomsbury.

Timofeeva, Oxana (2013). “Communism with a Nonhuman Face." e-flux 48 https:// www.e-flux.com/journal/48/60030/communism-with-a-nonhuman-face/.

Teubner, Gunther (2006). "Rights of Non-humans?: Electronic Agents and Animals as New Actors in Politics and Law." Journal of Law and Society 33.4: 497-521.

Whitehead, Alfred North (2015). The Concept of Nature [1920]. Cambridge: Cambridge University Press.

Whitman, Walt (1985). Leaves of Grass. New York: Norton.

Wolfe, Carey (2012). Before the Law: Humans and Other Animals in a Biopolitical Frame. Chicago: University of Chicago Press. 